\title{
Article
}

\section{Exploring aspects of physiotherapy care valued by breast cancer patients}

Pidlyskyj, K., Roddam, H., Rawlinson, G. and Selfe, J.

Available at http://clok.uclan.ac.uk/13733/

Pidlyskyj, K., Roddam, H. ORCID: 0000-0002-0637-1801, Rawlinson, G. and Selfe, J. (2014) Exploring aspects of physiotherapy care valued by breast cancer patients. Physiotherapy, 100 (2). pp. 156-161. ISSN 00319406

It is advisable to refer to the publisher's version if you intend to cite from the work. http://dx.doi.org/10.1016/j.physio.2014.03.006

For more information about UCLan's research in this area go to

http://www.uclan.ac.uk/researchgroups/ and search for < name of research Group>.

For information about Research generally at UCLan please go to http://www.uclan.ac.uk/research/

All outputs in CLoK are protected by Intellectual Property Rights law, including Copyright law. Copyright, IPR and Moral Rights for the works on this site are retained by the individual authors and/or other copyright owners. Terms and conditions for use of this material are defined in the policies page.

\section{CLoK}

Central Lancashire online Knowledge www.clok.uclan.ac.uk

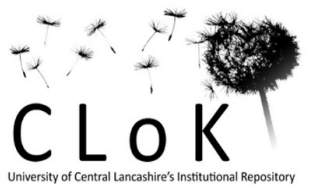




\section{Elsevier Editorial System(tm) for Physiotherapy Manuscript Draft}

Manuscript Number: PHYST-13-175R1

Title: Exploring aspects of physiotherapy care valued by breast cancer patients

Article Type: Original Research

Keywords: Patient care; Physiotherapy; Breast Cancer; Patient experience; Rehabilitation

Corresponding Author: Dr. Hazel Roddam, Ph.D

Corresponding Author's Institution: University of Central Lancashire

First Author: Karen E Pidlyskyj, MSc

Order of Authors: Karen E Pidlyskyj, MSc ; Hazel Roddam, Ph.D; Gillian Rawlinson, MSc; James Selfe, Ph.D 


\begin{tabular}{|c|c|c|}
\hline $\begin{array}{l}\text { Reviewer and } \\
\text { associate editor }\end{array}$ & Comment & Revision \\
\hline Reviewer 1 & $\begin{array}{l}\text { 1.Lack of specific } \\
\text { approach women wanted } \\
\text { or desired in each stage } \\
\text { or what specific care they } \\
\text { perceived as important }\end{array}$ & $\begin{array}{l}\text { Clarification within results/discussion } \\
\text { section }\end{array}$ \\
\hline $\begin{array}{l}\text { Reviewer } 1 \& \\
\text { Associate editor }\end{array}$ & $\begin{array}{l}\text { 2.Discussion really short } \\
\text { without any scientific } \\
\text { value }\end{array}$ & Discussion re-written following comments \\
\hline Reviewer 1 & $\begin{array}{l}\text { 3.Not sure what specific } \\
\text { patient-centred holistic } \\
\text { approach has been } \\
\text { implemented }\end{array}$ & Definition added see lines $115-117$ \\
\hline Reviewer 1 & 4.Misconception with title & Title amended: see title page \\
\hline $\begin{array}{l}\text { Reviewer } 1 \& 2 \& \\
\text { Associate editor }\end{array}$ & $\begin{array}{l}\text { 5.Did you have } \\
\text { appropriate ethical } \\
\text { approval and gain } \\
\text { consent? When was } \\
\text { consent gained? Consent } \\
\text { should be gained for both } \\
\text { the interviewing and } \\
\text { physical examination }\end{array}$ & $\begin{array}{l}\text { See lines } 87-91 \text { re ethical approval } \\
\text { See lines } 54-55 \text { re consent. No physical } \\
\text { examination was carried out during this } \\
\text { study therefore not stated }\end{array}$ \\
\hline Reviewer 1 & $\begin{array}{l}\text { 6.Confusion with use of } \\
\text { names rather than } \\
\text { subjects }\end{array}$ & $\begin{array}{l}\text { See line } 109 \text { for clarification. } \\
\text { Pseudonyms used in line with good } \\
\text { practice in qualitative research and } \\
\text { realist/personal style }\end{array}$ \\
\hline Reviewer 1 & $\begin{array}{l}\text { 7.Page 6, line 138: who } \\
\text { is 'her' here }\end{array}$ & $\begin{array}{l}\text { Line removed as results/discussion re- } \\
\text { written }\end{array}$ \\
\hline Reviewer 1 & $\begin{array}{l}\text { 8.Line 139: too many } \\
\text { 'hers' in sentence }\end{array}$ & $\begin{array}{l}\text { Line removed as results/discussion re- } \\
\text { written }\end{array}$ \\
\hline Reviewer 1 & 9.Conclusion missing & Lines $285-291$ \\
\hline Reviewer 1 & $\begin{array}{l}10 . I \text { am not quite sure } \\
\text { why and how they wrote } \\
\text { the participant's interview } \\
\text { section }\end{array}$ & Results/discussion section re-written \\
\hline $\begin{array}{l}\text { Reviewer } 2 \text { \& } \\
\text { Associate editor }\end{array}$ & $\begin{array}{l}\text { 11.Confused with regards } \\
\text { to the aims and methods, } \\
\text { would encourage } \\
\text { different way of } \\
\text { presenting results. Aims } \\
\text { not clearly presented, } \\
\text { need to be clear whether } \\
\text { exploring the experience } \\
\text { of physio in general or } \\
\text { comparing general } \\
\text { physio with specialist } \\
\text { service }\end{array}$ & Clarification re aims lines $43-46$ \\
\hline $\begin{array}{l}\text { Reviewer } 2 \text { \& } \\
\text { Associate editor }\end{array}$ & $\begin{array}{l}\text { 12.Stratification strange } \\
\text { as aim would suggest } \\
\text { authors are trying to } \\
\text { explore the breadth of } \\
\text { physio services for breast }\end{array}$ & Clarification re stratification lines $60-61$ \\
\hline
\end{tabular}




\begin{tabular}{|c|c|c|}
\hline & $\begin{array}{l}\text { cancer, rather than } \\
\text { compare specialist vs } \\
\text { non specialised service. } \\
\text { If the aim is to compare } \\
\text { specialist vs general then } \\
\text { I do not think the authors } \\
\text { have asked the right } \\
\text { questions to participants. } \\
\text { Not made clear why } \\
\text { participants divided into } 3 \\
\text { groups - if aims clearer } \\
\text { then perhaps } \\
\text { methodology may be } \\
\text { clearer }\end{array}$ & \\
\hline Reviewer 2 & $\begin{array}{l}\text { 13. How many patients in } \\
\text { each group }\end{array}$ & $\begin{array}{l}\text { Clarification re group numbers lines 95- } \\
96\end{array}$ \\
\hline Reviewer 2 & $\begin{array}{l}\text { 14.How many of the } \\
\text { patients from each group } \\
\text { volunteered for phase } 2 ? \\
\text { Which group did Laura, } \\
\text { Pamela and Chris belong } \\
\text { to? }\end{array}$ & $\begin{array}{l}\text { All participants volunteered for phase } \\
\text { two. For clarity and due to limitation of } \\
\text { word count phase one has been } \\
\text { excluded from the account reported in } \\
\text { this paper, this is referenced 'as part of a } \\
\text { larger study' line } 75\end{array}$ \\
\hline Reviewer 2 & $\begin{array}{l}\text { 15.Dual role clinician- } \\
\text { researcher big } \\
\text { confounding factor and } \\
\text { should be elaborated on. } \\
\text { The results should be } \\
\text { interpreted with care }\end{array}$ & $\begin{array}{l}\text { Clarification re dual role clinician- } \\
\text { researcher lines } 233-244\end{array}$ \\
\hline Reviewer 2 & $\begin{array}{l}16 . I \text { feel the researcher- } \\
\text { interviewer role should } \\
\text { also be clearly stated in } \\
\text { the methods }\end{array}$ & See lines $83-84$ \\
\hline $\begin{array}{l}\text { Reviewer } 2 \text { \& } \\
\text { Associate editor }\end{array}$ & $\begin{array}{l}\text { 17. Results should be } \\
\text { described in terms of } \\
\text { common themes } \\
\text { identified in Phase one. } \\
\text { Table } 1 \text { and figures } 1-3 \\
\text { not adequate in } \\
\text { explaining what themes } \\
\text { mean. Some of the } \\
\text { themes from phase } 1 \\
\text { should be discussed. }\end{array}$ & $\begin{array}{l}\text { Following serious consideration of the } \\
\text { reviewer feedback it has been decided to } \\
\text { exclude discussion of "phase one" in } \\
\text { order to focus on the main aim of the } \\
\text { study which was to explore patient } \\
\text { experience of the value of physiotherapy } \\
\text { in more depth. Therefore table one has } \\
\text { been removed. }\end{array}$ \\
\hline Reviewer 2 & $\begin{array}{l}\text { 18.Often combined } \\
\text { results and discussion } \\
\text { section, as it makes } \\
\text { sense to discuss the } \\
\text { themes and support them } \\
\text { with quotes as they are } \\
\text { presented }\end{array}$ & $\begin{array}{l}\text { See newly restructured } \\
\text { results/discussion section }\end{array}$ \\
\hline Reviewer 2 & $\begin{array}{l}\text { 19.If the authors wish to } \\
\text { present table } 1 \text { in relation } \\
\text { to each of the } 3 \text { groups, } \\
\text { an explanation should be } \\
\text { given as to why they } \\
\text { think certain themes were } \\
\text { not mentioned by certain } \\
\text { groups }\end{array}$ & $\begin{array}{l}\text { As "phase one" has been removed from } \\
\text { this report, the paper is now more } \\
\text { sharply focused on reporting and } \\
\text { analysis of the interviews }\end{array}$ \\
\hline Reviewer 2 & $\begin{array}{l}\text { 20.No need to present } \\
\text { data in this manner, as } \\
\text { no difference between }\end{array}$ & As above and stated lines $103-106$ \\
\hline
\end{tabular}




\begin{tabular}{|c|c|c|}
\hline & $\begin{array}{l}\text { the groups because the } \\
\text { numbers in some groups } \\
\text { were so small }\end{array}$ & \\
\hline Reviewer 2 & $\begin{array}{l}\text { 21.Encourage to provide } \\
\text { phase one demographics }\end{array}$ & $\begin{array}{l}\text { As explained above, "phase one" now } \\
\text { omitted from discussion }\end{array}$ \\
\hline Reviewer 2 & $\begin{array}{l}\text { 22. The authors should } \\
\text { examine phase } 1 \\
\text { demographic data and } \\
\text { see if there are any } \\
\text { trends between themes } \\
\text { and patients who have } \\
\text { different types of } \\
\text { treatment, or perhaps } \\
\text { patients of different ages, } \\
\text { or patients who may have } \\
\text { lymphoedema, compared } \\
\text { to those who do not }\end{array}$ & $\begin{array}{l}\text { The aim of the study was to explore in- } \\
\text { depth the experience of physiotherapy } \\
\text { care received by a small purposive } \\
\text { sample of patients with breast cancer. } \\
\text { The research design was not planned to } \\
\text { explore trends between different } \\
\text { treatments; that would need to be } \\
\text { addressed in other study designs. }\end{array}$ \\
\hline Reviewer 2 & $\begin{array}{l}\text { 23.An unexplored area is } \\
\text { timing of physio, how } \\
\text { does this impact on the } \\
\text { patient? Would the } \\
\text { patient have remembered } \\
\text { the info given at a time of } \\
\text { great stress? Further } \\
\text { discuss encouraged }\end{array}$ & See lines 203-207 \\
\hline Associate editor & $\begin{array}{l}\text { 24. Themes identified } \\
\text { from each group in phase } \\
\text { one (not just in table } \\
\text { form) and then these } \\
\text { expanded and discussed }\end{array}$ & $\begin{array}{l}\text { As explained above "phase one" now } \\
\text { omitted from the discussion }\end{array}$ \\
\hline Associate editor & $\begin{array}{l}25 . \text { One stated aim was to } \\
\text { better understand the } \\
\text { impact of specialist } \\
\text { service, but results from } \\
\text { phase } 2 \text { do not address } \\
\text { this }\end{array}$ & $\begin{array}{l}\text { Results/discussion re-written to address } \\
\text { this }\end{array}$ \\
\hline Associate editor & $\begin{array}{l}\text { 26.A lot of detail on the } \\
\text { individual participant } \\
\text { interviews - perhaps this } \\
\text { detail could go in } \\
\text { appendix and summary } \\
\text { presented in results and } \\
\text { comparison between } \\
\text { experiences of three } \\
\text { women discussed in } \\
\text { discussion section }\end{array}$ & $\begin{array}{l}\text { Results/discussion re-written to address } \\
\text { this }\end{array}$ \\
\hline Associate editor & $\begin{array}{l}\text { 27.It is not clear to which } \\
\text { sub group each of the } 3 \\
\text { participants belonged } \\
\text { and this should be made } \\
\text { clear and form part of the } \\
\text { discussion }\end{array}$ & See lines $110-111$ \\
\hline Associate editor & $\begin{array}{l}\text { Needs to be discussion } \\
\text { around comparison of } \\
\text { general with specialist } \\
\text { physio from results of } \\
\text { phase } 1 \text { and } 2 \text {. }\end{array}$ & $\begin{array}{l}\text { This was not the aim of the study, } \\
\text { discussion re-written for clarification }\end{array}$ \\
\hline
\end{tabular}




\section{Exploring aspects of physiotherapy care valued by breast cancer patients}

\section{Authors:}

Pidlyskyj, K. ${ }^{\mathrm{a}}$, Roddam, H. ${ }^{\mathrm{b}}$, Rawlinson, G. ${ }^{\mathrm{c}}$, Selfe, J. ${ }^{\mathrm{d}}$,

${ }^{\text {a }}$ Physiotherapy Department, Salford Royal NHS Foundation Trust, Salford M6 8HD (karen.pidlyskyj@srft.nhs.uk)

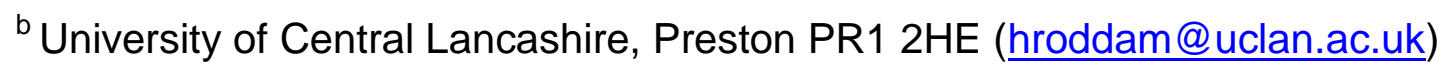

${ }^{\mathrm{C}}$ University of Central Lancashire, Preston PR1 2HE

(GRawlinson@uclan.ac.uk)

${ }^{d}$ University of Central Lancashire, Preston PR1 2HE (JSelfe1@uclan.ac.uk)

Corresponding author: Karen Pidlyskyj (0161 206 5328)

Word count: 2989 
Exploring aspects of physiotherapy care valued by breast cancer patients

\section{Introduction:}

2 Breast cancer has been the most common cancer in the United Kingdom since 1997

3 and accounts for $31 \%$ of all new cases of cancer in females [1]. The rate of new 4 diagnoses increases rapidly amongst those aged 40 years, rising from about 1 per 5100,000 in young adults to just over 400 per 100,000 in those aged over 85 years

6 [2]. Although much progress has been made in combating breast cancer, women

7 endure multiple assaults to the body from both the disease and treatments. For

8 some of the nearly three million people diagnosed annually [3], the life-prolonging

9 surgical and adjuvant therapies are associated with complications and side effects,

10 can lead to functional limitations, disability and have a negative impact on quality of

11 life.

13 As acknowledged in the National Cancer Survivorship Initiative (NCSI) Vision [4], the

14 next challenge is to "understand the needs of those living with breast cancer today and to develop models of care which meet their needs" (page 4). It also

16 acknowledges the need for services which are responsive to individual needs and 17 access to specialist care when needed.

19 It is recognised that breast cancer patients have specific support needs and if these 20 remain unmet, they are likely to have implications for long term rehabilitation 21 outcomes. Hence there is an urgent need for physiotherapists to develop effective and high quality rehabilitation protocols for breast cancer patients, to support their functioning and to prevent permanent disabilities $[5,6]$. 
Exploring aspects of physiotherapy care valued by breast cancer patients

The Specialist Breast Care Physiotherapy Service was first established as a pilot service in 2010, in accordance with National Institute for Health and Clinical Excellence guidelines (2004) [7] and the National Cancer Action Team 'Breast Cancer Rehabilitation Pathway' (2009) [8]. As outlined in the NCSI document (2010) [4] the Service has been designed to accommodate the increasing numbers of breast cancer survivors in the future and to optimise the use of NHS resources.

The Service has been developed to support patients at all stages of their breast cancer treatment pathway, with the provision of a Specialist Outpatient Service for treatment related problems; including shoulder dysfunction, arm and breast lymphoedema, reduced arm strength, scar tightness, myofascial dysfunction, axillary web syndrome, donor site morbidity following reconstruction and pain. The Service is delivered by a physiotherapist who specialises in the treatment of breast cancer patients and has extensive clinical experience working with this patient group. The need to evaluate the impact of the new Service was identified as a priority. Hence, the study aimed to explore the value of physiotherapy care received by patients who had accessed the new Specialist Breast Care Physiotherapy Service.

\section{The study objectives were to:}

- identify which aspects of care patients valued most and least

- gain insights into why these aspects were liked or disliked

- make recommendations for clinical care pathways based on outcomes 
Exploring aspects of physiotherapy care valued by breast cancer patients

50

51

52

53

54

55

56

57

\section{Method:}

Participants were recruited from a sampling frame of patients who had been referred to the Specialist Service and discharged within the last six months. The researcher accessed patient records to identify potential participants who met the inclusion criteria. Consent forms were sent by post with invitation to participate and an information sheet. Written consent was gained prior to taking part in the study.

In order to draw a representative sample from the population, a stratified purposeful sampling technique [9] was used; with the patients being stratified into one of three subgroups dependant on their previous physiotherapy experience. The researcher was interested to see whether the previous physiotherapy affected participant's experience of the Specialist Service. Group One patients had accessed the Specialist Service only, Group Two patients had accessed the Specialist Service and had previous experience of physiotherapy locally and Group Three patients had accessed the Specialist Service and had previous experience of physiotherapy outside this locality. Those selected were contacted by post and asked to telephone the Physiotherapy Department if they agreed to take part.

The inclusion criteria were any patients who had been referred to the Specialist Service following a diagnosis of breast cancer, since June 2010. Any patients identified as requiring full-time cognitive or physical care, those unable to participate in a group setting or requiring a translator or a family member to communicate were excluded. 
Exploring aspects of physiotherapy care valued by breast cancer patients

74 This paper reports the results of in-depth one to one interviews which were

\section{Results \& discussion:} interpret the data [10]. conducted as part of the larger study involving three groups described above. One participant from each subgroup was selected using a random number table. The order of the interviews was also generated via this method. Items developed from the earlier part of the larger study were used to guide the interview schedule of openended questions. A consistent scripted protocol was followed for each interview, which was audio-recorded then transcribed and lasted between 30-45 minutes. The researcher conducted the interviews in a dual role alongside being the physiotherapist who had delivered care as part of the Specialist Service. The implications of this dual clinician-researcher role are further discussed in the 'limitations' section below. A thematic network analysis approach was adopted to

An application for full NHS ethical approval (Ref 12/NW/0009) was submitted, the committee decision was that the study was a service evaluation and therefore did not require any NHS ethics approvals. Governance approval was obtained from the host NHS Trust R\&D Department (Ref 2011/266can) and ethical approval was obtained from the University ethics panel (Ref BuSH 041).

Nineteen female participants were recruited. Due to the stratification dependant on previous physiotherapy experience, the numbers in each group varied; in group one there were seven participants two in group two, and ten in group three. 
Exploring aspects of physiotherapy care valued by breast cancer patients

98 As stated above one participant was randomly selected to take part in an in-depth

99 interview from each subgroup. It is beyond the remit of this paper to fully present the

100 findings from each of the interviews, and as the participants were stratified into sub-

101 groups related to previous experience of physiotherapy, the findings cannot be

102 combined together as one set of outcomes. However within this small sample,

103 previous experience of physiotherapy had not affected the perceived value of

104 experience of the Specialist Service; therefore comparisons between findings can be 105 made.

107 The results are presented as an analysis of themes generated from each interview

108 (see Figures One, Two and Three), followed by a discussion of themes below.

109 The names quoted are pseudonyms to protect the identity of the participants. Laura

110 was selected from Group One, Pamela from Group Two and Chris from Group

111 Three.

113 All three interviews highlighted the theme of the importance of a patient-centred

114 holistic approach to care. As defined by McEvoy and Duffy (2008) [11] in their

115 concept analysis study, holistic care embraces the mind, body and spirit of the

116 patient, in a culture that supports a therapeutic relationship, resulting in wholeness,

117 harmony and healing. In their qualitative study in 2011, Kidd et al [12] found that

118 patients insisted that the physiotherapist should locate the patient at the centre of the

119 therapeutic encounter, and make them feel understood and respected. 
Exploring aspects of physiotherapy care valued by breast cancer patients

121 The value of receiving specialist physiotherapy from an experienced clinician was

122 also consistent throughout the three interviews, which fulfils the recommendations of

123 the NCSI document [4] as discussed in the introduction, in providing access to a

124 Specialist Service. Participants talked about the confidence they felt in being treated

125 by a therapist who specialised in treating breast cancer patients and had experience

126 in the management of post treatment dysfunction.

127

128

129

130

131

132

133

134

135

136

137 The impact of physical improvement was stated in all three interviews. In the

The participants felt the Service had met their physiotherapy needs; emotionally and psychosocially, as well as physically. This perceived value of both physical and psychological support is very similar to the findings of Lattanzi et al (2010) [13] where participants acknowledged the importance of the therapist providing this support, especially for those who may not have anyone else with whom to share their struggles. Their study in 2010 was methodologically very similar to this study; with a similar sampling technique, inclusion criteria, overall findings and subsequent recommendations.

'Individualised care' theme in Figure one, Laura reported 'it was motivation, even in the space of 2 days I could see a difference' (line 50). Pamela stated 'my god it helped. I think it was within a couple of weeks I was able to move my arm. And it was brilliant' (lines 178-179) in the 'Physiotherapy experience' theme in Figure Two. In the 'Self-awareness' theme in Figure Three, Chris states 'I didn't realise how restricted my arm was till I met you' (Line 57) and 'you could actually see physically the progression of it which was fantastic' (Lines 59-60). 
Exploring aspects of physiotherapy care valued by breast cancer patients

146 The general consensus was that the participants reported an overall positive

147 experience. All three participants expressed gratitude at being able to access the

148 Specialist Service. As stated in the 'Physiotherapy experience' theme in Figure Two

149 Pamela talked about the therapist taking a personalised approach, stating 'it was just

150 as though you had just time for me, like I was the only one who mattered' (lines 238-

$151239)$.

152

153 The value of individualised care, goal setting and seeing continuous improvement

154 was consistent for both Laura and Chris. Laura talked about the importance of goal

155 setting and the value of monitoring her progress with her physiotherapist, stating ' It

156 had a big impact in that I had something to work towards. It stopped my stressing

157 about what else was going on; I had something to focus on' (line 45). As this

158 empowered her and built her confidence, her therapy was delivered using a more

159 'hands-off' approach.

160

161 Participants talked about valuing the therapist's knowledge regarding the impact of a breast cancer diagnosis and subsequent treatment physically, emotionally and psychologically. All three participants focused strongly on the value of the provision

164 of emotional support, specifically motivation, positivity and encouragement. As stated

165 within the 'Support' theme in Figure Three, Chris described the emotional support

166 provided by her therapist as giving her a kind of 'mental stability' and stated 'It gave

167 me a lot of reassurance that I wasn't on my own and that I was coping with it as well

168 as could be expected' (line 223). 
Exploring aspects of physiotherapy care valued by breast cancer patients

170 Chris talked about the value of seeing the same therapist throughout her treatment,

171 and the impact this had on being able to form a therapeutic relationship. She

172 reflected that the support provided by her therapist gave her the confidence to utilise

173 other support and services and also played a key part of enabling her return to work,

174 which was also valued by Laura.

175

176 The importance of educational support and effective communication was recognised

177 by Pamela and Chris. Chris valued the early identification and referral onwards with

178 regards to her lymphoedema. She also found her experience gave her a better self-

179 awareness in terms of her physical limitations and she felt empowered by this.

180

181 When describing the physiotherapy experience as a whole, Pamela compared her previous experience of physiotherapy, where she struggled to get the help she needed, to the positive experience and relationship she developed with her therapist.

184 She talked about the improvement in both physical functioning and the impact this 185 subsequently had on her confidence and family role. She discussed the impact of having to rely on others to help her do the tasks at home she previously carried out and through improvement in movement and function and reduction in pain, stated 'Well I felt as though l'd got my life back again. So now I don't have to ask anybody 189 for anything' (line 202).

191 When Laura described her physiotherapy experience, she valued the importance of early intervention post diagnosis and a flexible, easily accessible service. Laura did feel however that the service could be improved by the availability of online access.

194 This service development has been discussed with the Physiotherapy Manager, as a 
Exploring aspects of physiotherapy care valued by breast cancer patients

195 way to enhance communication with patients. She also liked the multi- disciplinary

196 approach to her care. She specifically reflected that she felt well supported with the

197 awareness that her care was being provided by a team who regularly communicated

198 with each other, thus creating a holistic approach and facilitating referral onto other

199 disciplines.

200

201 Chris described her referral to the Specialist Service happened 'by chance' as she hadn't retained the information received on the ward post-operatively regarding selfreferral. This confirms findings of Larsson et al (2008) [14] who acknowledge the fact that women may still be in a state of shock when they go through surgery and cannot be expected to be receptive to information. Chris felt that the Service would be improved by the introduction of a pre-operative assessment and routine follow-up with the physiotherapist.

209 The theme of body image was explored in Chris's interview, when she talked about when her therapist began treating her mastectomy scar. Her 'hands-on'

211 physiotherapy approach enabled patient-clinician exploration of how her mastectomy

212 had impacted on her self-image. Chris reflected that the impact of her therapist

213 treating her mastectomy scar affected her both emotionally and also physically, as

214 she was able to touch her scar and massage it, stating 'It would have been something I would have blocked out completely and I wouldn't have even wanted to look at it and now when I have a shower I do go through the massage and things like

217 that' (line 446). Talking about this actually made Chris cry, demonstrating how

218 powerful and meaningful the experience was to her. This demonstrates the need for 
Exploring aspects of physiotherapy care valued by breast cancer patients

219 therapist's to develop the ability to deal with sensitive issues and communicate 220 effectively.

222 Interestingly, the environment of the physiotherapy service provision, that takes

223 place in the Outpatient Physiotherapy Department, usually in a cubicle surrounded

224 by curtains, was not raised as an issue. It had been felt by the therapist that this

225 environment may not be as conducive to patient satisfaction as a more private

226 clinical area, but in fact Chris stated she preferred the therapy taking place here as it

227 was easier to access than the main outpatient area of the hospital.

\section{Limitations:}

230 This study comprised a relatively small sample size from one geographical site,

231 which limits the direct transferability of the findings. However the in-depth analysis of

232 these data has generated important issues related to the patient experience of care.

233 The potential bias of the lead investigator's dual clinician-researcher role is

234 acknowledged. As described by Yanos and Ziedonis (2006) [15], the dual role of

235 clinician-researcher can facilitate the development of clinically relevant research.

236 However, there is a risk that this can pose both ethical and role conflicts for the

237 researcher. They conclude that the establishment of an 'integrated identity' is

238 ultimately the most comprehensive means of balancing and prioritising ethical

239 issues. 
Exploring aspects of physiotherapy care valued by breast cancer patients

240 The complexity of clinical research does not permit a clean cut between therapeutic

241 and non-therapeutic studies, therefore alternating between a clinical or research

242 orientation would not prove satisfactory. The clinician-researcher aimed to maintain a

243 conception of moral identity that integrated the roles of the clinician and researcher,

244 without giving predominance to one or the other [16].

\section{Implications for future research:}

247 The importance of an effective therapeutic relationship that can develop between

248 patient and therapist has been demonstrated. Further studies to explore the concept

249 of therapeutic relationships are needed to obtain a more conclusive understanding of

250 the influence of the alliance and its effects on treatment outcomes $[12,17,18]$.

251 The impact of the development of lymphoedema was briefly touched upon in both

252 phases of the study. Further exploration of this area was beyond the scope of this

253 study, but the need for evaluation of patient experience of this chronic condition [19]

254 is highlighted.

255 Within the sample of participants that took part in the study, previous experience of

256 physiotherapy did not affect the perceived value of the experience of a Specialist

257 Service. This suggests that the stratification of participants into sub-groups

258 dependant on their previous experience of physiotherapy may not have been

259 necessary. This has implications for future research in terms of research design with

260 this patient population. 
Exploring aspects of physiotherapy care valued by breast cancer patients

\section{Implications for practice:}

263 As the role of the physiotherapist in providing rehabilitation for breast cancer patients

264 emerges, so does the need to evaluate interventions, demonstrate effectiveness and

265 review current service provision, in order to establish best practice and to secure

266 future service provision. The Specialist Service that has been evaluated in this study

267 was developed in response to the identification of need and aims to deliver a holistic

268 and individualised approach to care and support patients to return to function and

269 optimise quality of life, following a diagnosis of breast cancer. The outcomes of this

270 study will be used to make recommendations for future clinical care pathways and

271 support continued service provision.

272 This study supports the need for physiotherapy at all stages of the treatment

273 pathway, following a diagnosis of breast cancer. What has emerged from this study

274 is the importance of treating a patient 'as a whole'; incorporating both the physical

275 and the psychological and emotional impact of receiving a diagnosis of breast cancer

276 and its subsequent treatment. The importance of the therapeutic relationship

277 between patient and therapist has been identified, and the positive impact this can

278 have on overall satisfaction and treatment outcomes.

279 Breast cancer patients often have unmet information needs and the importance of

280 educational support and effective communication has been demonstrated. The

281 recommendation of the introduction of a pre-operative assessment and routine

282 follow-up with the physiotherapist is also supported in previous literature [13, 20, 21,

283 22] and therefore has implications for clinical practice. 
Exploring aspects of physiotherapy care valued by breast cancer patients

\section{Conclusion:}

286 These findings highlight the importance of a patient-centred holistic approach to

287 care. The importance of the physiotherapist locating the patient at the centre of the

288 therapeutic encounter confirms previous findings [12, 23].The value of receiving

289 specialist physiotherapy from an experienced clinician was also consistent

290 throughout the three groups, which is in line with current government

291 recommendations [4].

293 Key messages:

- Participants value a patient-centred holistic approach to care and access to a Specialist Service with an experienced clinician.

- Alongside the value of physical improvement, the importance of the therapeutic alliance and the value of psychological, emotional and educational support helped the participants to feel more empowered in their own recovery.

300 Acknowledgements:

301 The authors are grateful to the participants and for the support of employers who made this study possible.

304 Ethical approval: 
Exploring aspects of physiotherapy care valued by breast cancer patients

306 Salford Research and Development Number: 2011/266can

307 University of Central Lancashire Reference Number: BuSH 041

308

309 Funding: Nil

310 Conflict of interest statement: Nil

312 References:

314 [1] Cancer Research UK (2012) Breast cancer incidence statistics [online] last

315 accessed 13 December 2012 at URL http://www.cancerresearchuk.org/cancer-

316 info/cancerstats/types/breast/incidence/uk-breast-cancer-incidence-statistics

318 [2] Office for National Statistics 2005-2009 (2011) Cancer survival in England:

319 patients diagnosed 2005-2009 and followed up to 2010 [online] last accessed 13

320 December 2012 at URL http://www.ons.gov.uk/ons/rel/cancer-unit/cancer-

321 survival/2005-2009--followed-up-to-2010/summary-cancer-survival-2005-2009--

322 followed-up-to-2010.html

324 [3] Harris, S.R., Schmitz, K.H., Campbell, K.L., McNeely, M.L. (2012) Clinical 325 Practice Guidelines for Breast Cancer Rehabilitation: Syntheses of Guideline

326 Recommendations and Qualitative Appraisals Cancer April pp.2312-2324

328 [4] Department of Health, Macmillan Cancer Support and NHS Improvement (2010)

329 The National Cancer Survivorship Initiative Vision [online] last accessed 13

330 December 2012 at URL http://www.ncsi.org.uk/wp-content/uploads/NCSI-Vision-

331 Document.pdf

333 [5] Gomide, L.B., Matheus, J.P.C., Candido dos Reis, F.J. (2007) Morbidity after 334 breast cancer treatment and physiotherapeutic performance International Journal of 335 Clinical Practice 61(6) pp.972-982 
Exploring aspects of physiotherapy care valued by breast cancer patients

337 [6] Campbell, K.L., Pusic, A.L., Zucker, D.S., McNeely, M.L., Binkey, J.M., Cheville, 338 A.L., Harwood, K.J. (2012) A prospective model of care for breast cancer

339 rehabilitation: Function Cancer April pp.2300-2311

341 [7] National Institute for Health and Clinical Excellence (2004) Improving Supportive

342 and Palliative Care for Adults with Cancer [online] last accessed 12 November 2012 at URL http://www.nice.org.uk/nicemedia/live/10893/28816/28816.pdf

[8] National Cancer Action Team (2009) Rehabilitation Care Pathway for breast cancer [online] last accessed 12 November 2012 at URL http://ncat.nhs.uk/ourwork/living-beyond-cancer/cancer-rehabilitation

[9] Patton, M.,Q. (2002) Qualitative research and evaluation methods (3rd edition) Thousand Oaks, CA: Sage Publications

[10] Attride-Stirling, J. (2001) Thematic networks: an analytic tool for qualitative research Qualitative Research 1(3) pp.385-405

[11] McEvoy, L., Duffy, A. (2008) Holistic practice - A concept analysis Nurse Education in Practice [online] last accessed 14 May 2013 at URL http://www.sciencedirect.com/science? ob=MiamilmageURL\& cid=272450\& user=1 1804460\& pii $=S 147159530800019 X \&$ check $=y \&$ origin=article\& zone=toolbar\& co verDate $=2008-$ Nov-30\&view $=c$ \&originContentFamily=serial \&wchp=dGLbVBAzSkzS\&md5=3d86295d6e4fe1b66f086cfe79cffd89\&pid=1-s2.0S147159530800019X-main.pdf

[12] Kidd, M.O., Bond, C.H., Bell, M.L. (2011) Patients' perspectives of patientcentredness as important in musculoskeletal physiotherapy interactions: a qualitative study Physiotherapy 97 pp.154-162

[13] Lattanzi, J.B., Giuliano, S., Meehan, C., Sander, B., Wootten, R., Zimmerman, A. (2010) Recommendations for Physical and Occupational Therapy Practice from the Perspective of Clients Undergoing Therapy for Breast Cancer-related Impairments Journal of Allied Health 39 pp.257-264 
Exploring aspects of physiotherapy care valued by breast cancer patients

372 [14] Larsson, I.L., JÖnsson, C., Olsson, A.C., Gard, G. (2008) Women's experience

373 of physical activity following breast cancer treatment Scandinavian Journal of Caring

374 Science 22 pp.422-429

[15] Yanos, P.T., Ziedonis, D.M. (2006) The Patient-Orientated Clinician-Researcher:

Advantages and Challenges of Being a Double Agent Psychiatric Services 57(2) pp.249-253

379

[16] Miller, F.G., Rosenstein, D.L., DeRenzo, E.G. (1998) Professional integrity in

clinical research The Journal of the American Medical Association 280(16) pp.1449-

[17] Pinto, R.Z., Ferreira, M.L., Oliveira, V.C., Franco, M.R., Adams, R., Maher, C.G.,

Ferreira, P.H. (2012) Patient-centred communication is associated with positive therapeutic alliance: a systematic review Journal of Physiotherapy 58 pp.77-87

[18] Hall, A.M., Ferreira, P.H., Maher, C.G., Latimer, J., Ferreira, M.L. (2010) The Influence of the Therapist-Patient Relationship on Treatment Outcome in Physical Rehabilitation: a Systematic Review Physical Therapy 90 pp.1099-1110

[19] Thomas-MacLean, R., Miedema, B., Tatemichi, S.R. (2005) Breast cancerrelated lymphedema: Women's experiences with an underestimated condition

[20] Johansson, K., Ingvar, C., Albertsson, M., Ekdahl, C. (2001) Arm Lymphoedema, Shoulder Mobility and Muscle Strength after Breast Cancer Treatment - a Prospective 2-year Study Advances in Physiotherapy 3(55) pp.55-66

[21] Binkley, J.M., Harris, S.R., Levangie, P.K., Pearl, M., Guglielmino, J, Kraus, V., Rowden, D. (2012) Patient Perspectives on Breast Cancer Treatment Side Effects and the Prospective Surveillance Model for Physical Rehabilitation for Women With 
Exploring aspects of physiotherapy care valued by breast cancer patients

405 [22] Springer, B.A., Levy, E., McGarvey, C., Pfalzer, L.A., Stout, N.L., Gerber, L.H., 406 Soballe, P.W., Danoff, J. (2010) Pre-operative assessment enables early diagnosis 407 and recovery of shoulder function in patients with breast cancer Breast Cancer 408 Research Treatment 120 pp.135-147

409

410 [23] Gilbar, O. (1996) Introducing a biopsychosocial approach in an oncology 411 institute: a case study International Social Work 39 pp.163-176 
Figure One: Laura's interview

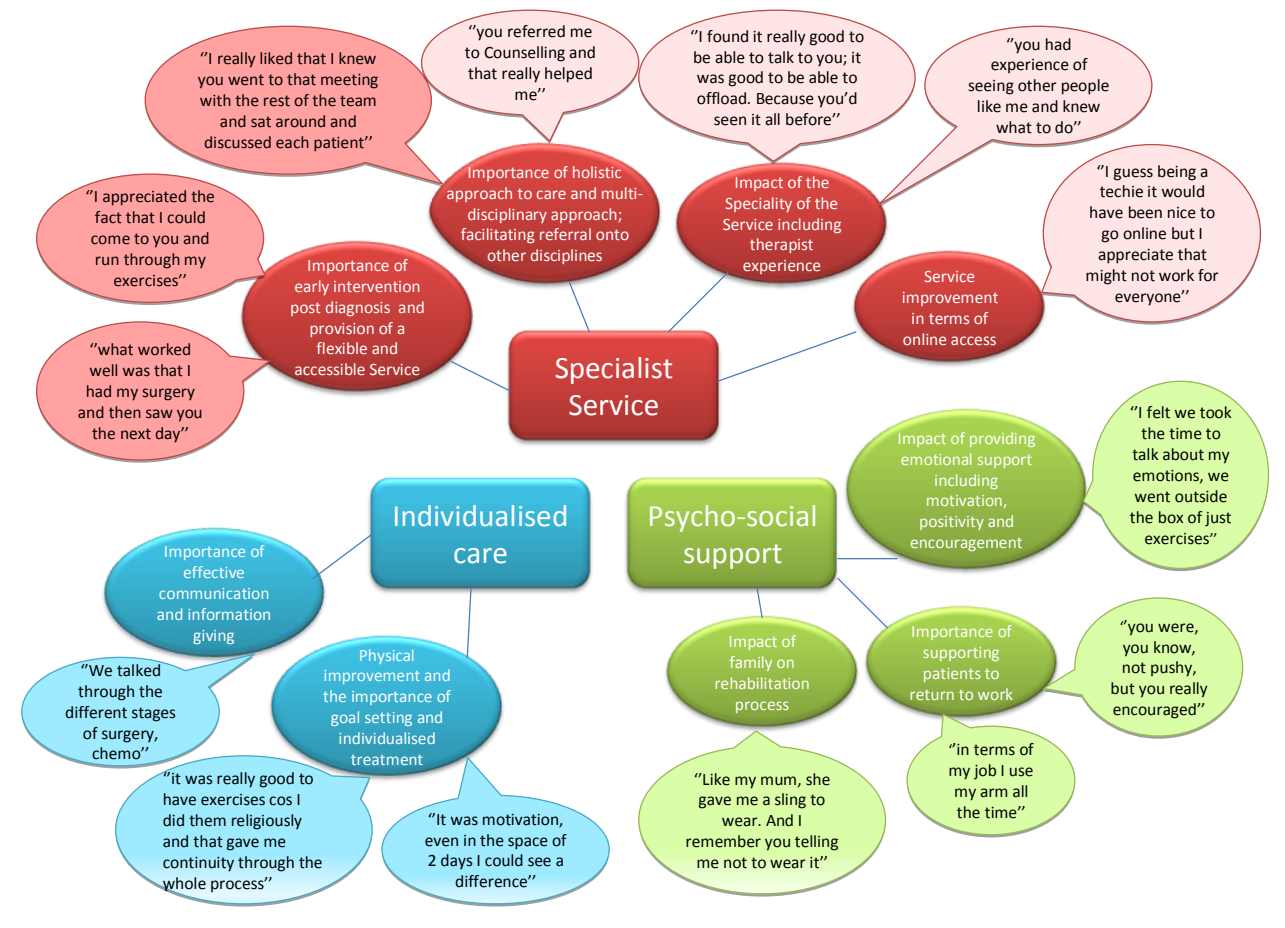

Figure Two: Pamela's interview

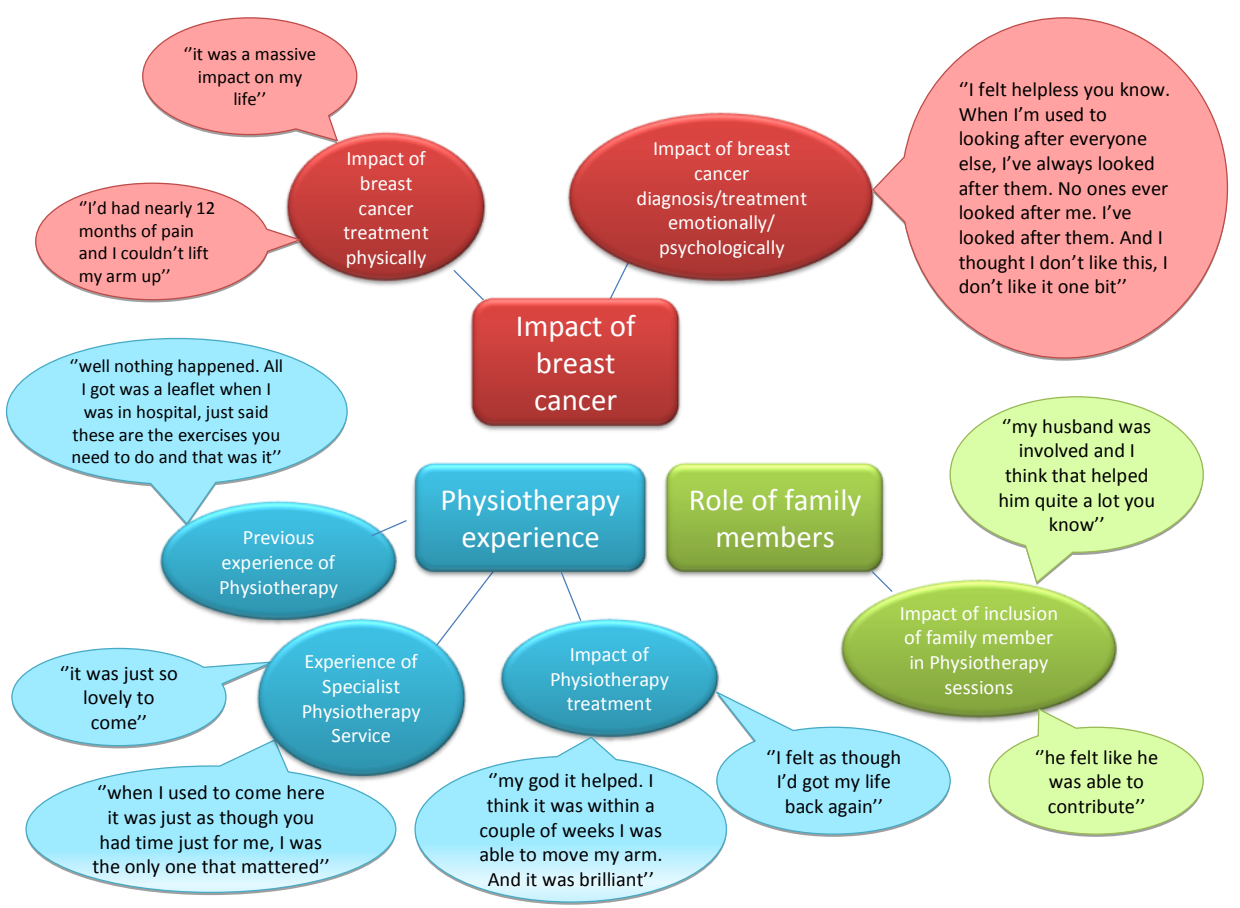


Figure Three: Chris' interview

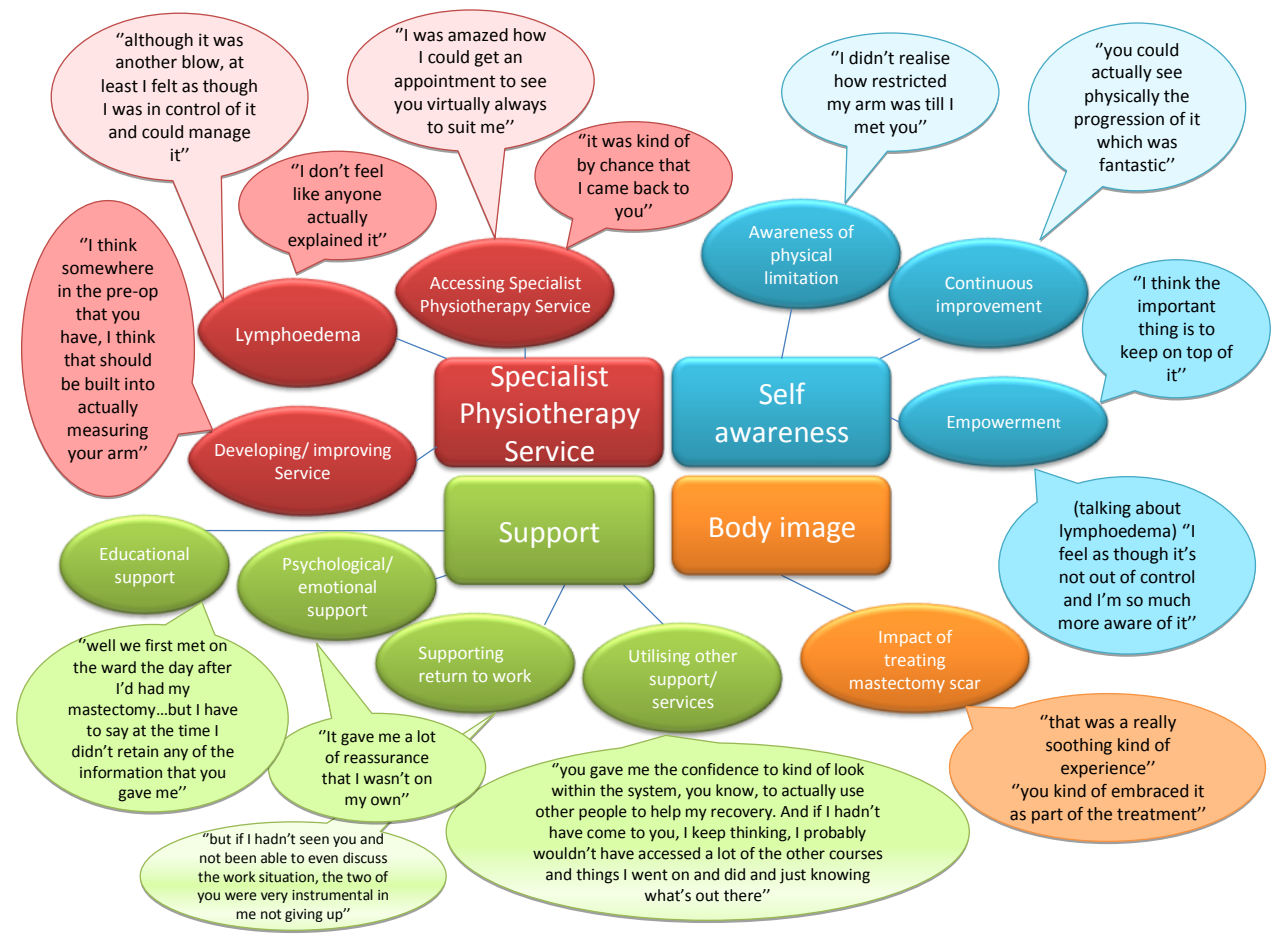


Exploring aspects of physiotherapy care valued by breast cancer patients

\section{Abstract}

Objective: To explore the reported value of physiotherapy care received by patients who had accessed a Specialist Breast Care Physiotherapy Service.

Design: Exploratory qualitative study using in-depth interviews to explore aspects of physiotherapy care valued by breast cancer patients. Thematic network analysis was used to interpret the data and bring together the different experiences of the participants and identify common themes.

Setting: Physiotherapy Department at a NHS Foundation Trust Teaching Hospital.

Participants: Nineteen participants were recruited and three were selected to take part in the in-depth interviews. All participants had received physiotherapy care from a Specialist Breast Care Physiotherapy Service and had been discharged within the last six months.

Results: Participants valued a patient-centred holistic approach to care and access to a Specialist Service with an experienced clinician. In particular the importance of the therapeutic alliance and the value of psychological, emotional and educational support emerged, with the participants feeling empowered in their recovery. 
Exploring aspects of physiotherapy care valued by breast cancer patients

\section{Conclusion and clinical implications:}

Participants reported an overall positive experience of their physiotherapy care. This study supports the need for service providers to evaluate their current physiotherapy provision and subsequently develop Specialised Services to meet the physiotherapy needs of breast cancer patients throughout all stages of their treatment pathway from the delivery of preoperative care through to post-treatment follow-up.

Keywords: Patient care; Physiotherapy; Breast Cancer; Patient experience; Rehabilitation 
03.03.14

Please find attached our paper submission entitled "Exploring aspects of physiotherapy care valued by breast cancer patients".

I can confirm that this is original research which has not been submitted elsewhere for publication.

I will be pleased to hear from you in due course about the review progress.

Yours sincerely,

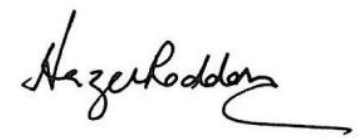

Dr Hazel Roddam

Principal Lecturer in Research

Allied Health Professions Research Unit

SSTO, Greenbank GR 161

University of Central Lancashire

Preston PR1 2HE

Direct Line: 01772895484

http://www.uclan.ac.uk/staff profiles/dr hazel roddam.php

Co-Director, Advancing Dysphagia Practice http://dysphagiapractice.blogspot.co.uk/ Chair, Cumbria and Lancashire Allied Health Professions Research Network

http://uclanahp.blogspot.co.uk/p/about-us.html

Royal College of Speech and Language Therapists www.rcslt.org 